\title{
Late Mesoproterozoic low-P/T-type metamorphism in the North Wulan terrane: Implications for the assembly of Rodinia
}

\author{
LU WANG ${ }^{1}$, STEPHEN T JOHNSTON ${ }^{2}$, NENGSONG \\ $\mathrm{CHEN}^{3}$ AND BIN XIA ${ }^{4}$ \\ ${ }^{1}$ Zhejiang University \\ ${ }^{2}$ University of Alberta \\ ${ }^{3}$ China University of Geosciences (Wuhan) \\ ${ }^{4}$ China University of Geosciences \\ Presenting Author: wanglucug2@gmail.com
}

Regional metamorphism provides critical constraints for unravelling lithosphere evolution and geodynamic settings, especially in an orogenic system. Recently, there has been a debate on the Rodinia-forming Tarimian orogeny within the Greater Tarim block in NW China. The North Wulan terrane, involved in the Paleozoic Qilian Orogen, was once part of the Greater Tarim block. This investigation of petrography, wholerock and mineral geochemistry, phase equilibrium modelling and in situ monazite $\mathrm{U}-\mathrm{Pb}$ dating of garnetite, pelitic gneiss and quartz schist samples from the Statherian-Calymmian unit of the North Wulan terrane provides new constraints on the evolutionary history of the Greater Tarim block at the end of Mesoproterozoic during the assembly of Rodinia. The studied samples yielded three monazite $\mathrm{U}-\mathrm{Pb}$ age groups of $\sim 1.32 \mathrm{Ga}$, $1.1 \mathrm{Ga}$ and $0.45 \mathrm{Ga}$ that are interpreted to be metamorphic in origin. The tectonic significance of the early $\sim 1.32 \mathrm{Ga}$ metamorphism is uncertain and may indicate an extensional setting associated with the final breakup of Columbia. The $\sim 1.1$ Ga low- $P / T$ type granulite-facies metamorphism is well preserved and characterized by a clockwise $P-T$ path with a minimum estimation of $\sim 840-900{ }^{\circ} \mathrm{C}$ and $\sim 7-11$ kbar for peak metamorphism, followed by post-peak decompression and cooling. A tectonothermal disturbance occurred at $\sim 0.45 \mathrm{Ga}$, but with limited influence on the pre-existing mineral compositions of the studied samples. The characteristics of the metamorphism indicate an arc-backarc environment with ongoing subduction of oceanic lithosphere at $\sim 1.1 \mathrm{Ga}$. Combined with the previous studies, we suggest that the Greater Tarim block probably experienced a prolonged subduction-to-collision process at 1.1-0.9 Ga during the assembly of Rodinia, with a position between western Laurentia and India-East Antarctica. 